\title{
The Evaluation of Agricultural Land Use Sustainability in the Post- Socialist Camp Countries: Methodological and Practical Aspects
}

\author{
Olena Kotykova ${ }^{1}$, Mykola Babych $^{2}$ \\ ${ }^{1}$ Mykolayiv National Agrarian University, Ukraine \\ ${ }^{2}$ Admiral Makarov National University of Shipbuilding, Ukraine
}

\begin{abstract}
An effective implementation of the sustainable use of agricultural land program is impossible without reliable results of the current state of the problem. In this sense, the correct selection of indicators and methods for determining the level of stability is important. The authors proposes the definition of the agricultural land use sustainability integral indicator based on three methodological approaches: the construction of the indicators system, each of them reflects some aspects of the land use sustainability at the macro level (according to the specific issues); the construction of the integral indicator for comparing the countries' land use sustainability. According to the given methods it has been proved that agricultural land use in the countries of the post-socialist camp has a positive dynamics, but the sustainability indicators for all indicators have not achieved yet. This study was supported in part by the Erasmus SUPPA program - Jean Monnet Associations Application No 611556-EPP-1-2019-1-UA-EPPJMO-SUPPA.
\end{abstract}

\section{Keywords}

Sustainability, land use, method, methodology, approaches, criteria, formulas.

Kotykova, O. and Babych, M. (2021) "The Evaluation of Agricultural Land Use Sustainability in the Post-Socialist Camp Countries: Methodological and Practical Aspects", AGRIS on-line Papers in Economics and Informatics, Vol. 13, No. 2, pp. 59-78. ISSN 1804-1930. DOI 10.7160/aol.2021.130205.

\section{Introduction}

In the former Soviet Union, among the 15 republics the Ukraine was "the breadbasket" of the state: the best black soil; a high standard of culture, deep roots and traditions of the grain growing; a hardworking nation. In the "Treatise on taxes and contributions" Petty says that labor is the father of wealth, and land is the mother (Petty, 1769). It is hard to disagree with the prominent economist's opinion. So, are the Ukrainians really rich and well fed?

There are different points of view on the fact what kind of the country's development should be in general and agricultural land use in particular. All of them have their right to exist, but there is a problem - what is the ultimate goal of their implementation? For example, the draft of the State Target Program of the agricultural sector for the period to 2020 provides the following effect as the expected result and the effectiveness of the Program: the increase in the volume of gross agricultural production in all categories of farms (2016). And the Ukrainians remember the 30-es years of the last century and what price they paid for the imperial ambitions of the Soviet Union. During that period, Stalin also aimed to increase the production volumes and export potential. We can assess the situation from the perspective of modernity: the volumes of the grain production in the country during 2013-2018 were the highest in the last twenty-five years (Figure 1), the wheat export from Ukraine during the last six years increased by $42 \%$, and the real incomes of the population decreased by $44 \%$ (Figure 2 ).

Of course, it does not mean that you need to produce or sell less - you need to properly define the purpose and objectively evaluate the outcomes. Who needs a high economic performance if it does not give any social effect and worsens the ecological situation?

In our opinion, such effects as the increase of the production volumes and that of the export potential are not the sustainable development goals, 


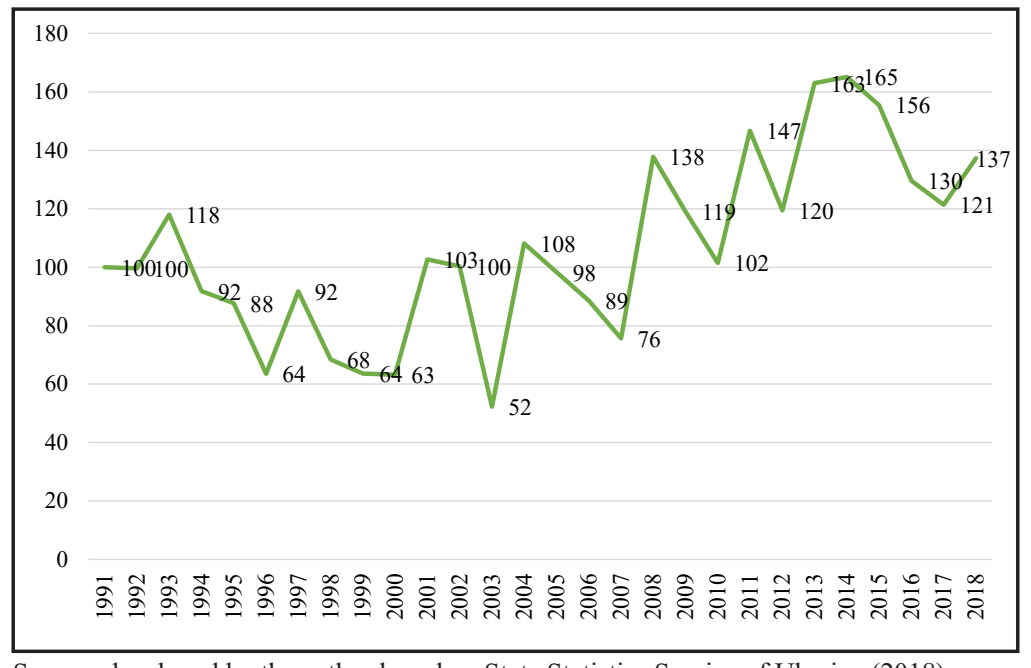

Source: developed by the author based on State Statistics Service of Ukraine (2018)

Figure 1: The indices of grain and leguminous crops production volumes in Ukraine, \%.

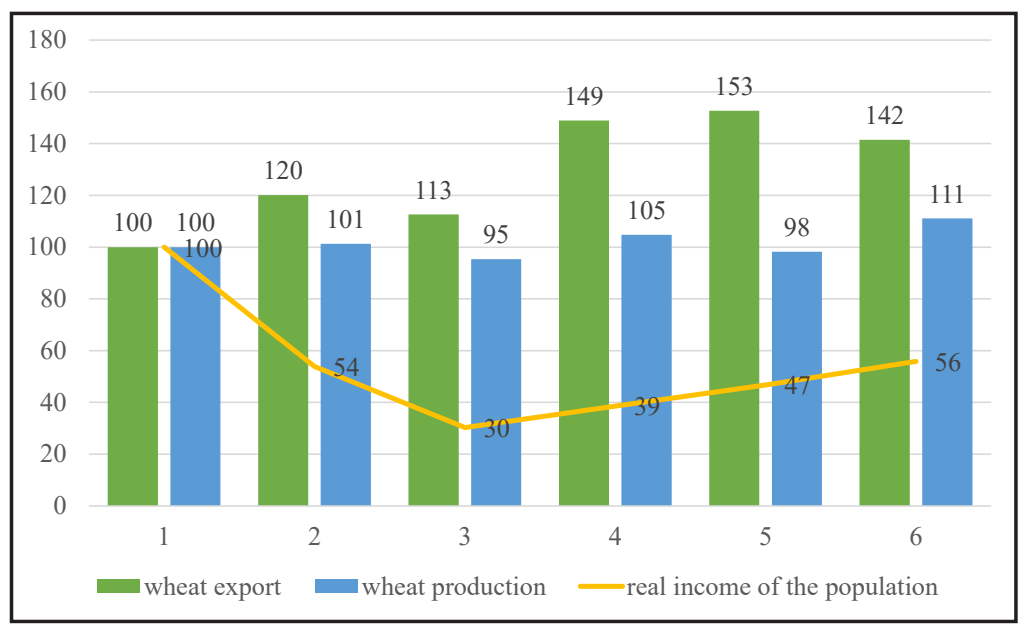

Source: developed by the author based on State Statistics Service of Ukraine (2018)

Figure 2: The indicators of the real income of the population, production volumes and wheat export in Ukraine, \% .

these and/or other positions may be the objectives for sustainability. We are convinced that sustainability of the agricultural land use can decide for at least two global world problems for the Ukrainians - food security and poverty reduction in rural areas.

This is why it is necessary to change priorities and determine the following: what indicators are really important and, based on the results, develop and implement the development program.

There are several approaches to the construction of the sustainability assessment indicators system. From the analysts' point of view, the most convenient way for decision-making is to determine a unified integral indicator, but according to the methodology, it is difficult to develop such kind of an indicator.
Thus, the methodology proposed by scientists (Kotykova et al., 2019) for assessing the sustainability of agricultural land use development at the macro level using the integral indicator is recognized as imperfect: the results of the evaluation will have different interpretations depending on the objective factors, which may ultimately influence the outcome both positively and negatively.

The same conclusion can be drawn from the results of "Global human appropriation of net primary production doubled in the 20th century" research, the authors of which note that "The rise in efficiency is overwhelmingly due to increased crop yields, albeit frequently associated with substantial ecological costs, such as fossil energy inputs, soil degradation, 
and biodiversity loss. If humans can maintain the past trend lines in efficiency gains, we estimate that HANPP might only grow to $27-29 \%$ by 2050 , but providing large amounts of bioenergy could increase global HANPP to $44 \%$. This result calls for caution in refocusing the energy economy on land-based resources and for strategies that foster the continuation of increases in land-use efficiency without excessively increasing ecological costs of intensification" (Krausmann et al., 2013).

So an objective assessment can only be achieved if all significant influencing factors are included into analysis' system in their interconnection and interdependence.

The development of agricultural land use is largely determined by the population's diet, natural and climatic conditions.

This thesis is confirmed by the results of the research by Lacirignola et al. (Lacirignola et al., 2014) "Immediate action is required in the Mediterranean to address environmental degradation that is mainly driven by consumption patterns. Increasing stress on biological and social systems is put by unsustainable consumption patterns. Food consumption patterns are important drivers ofenvironment degradation. The objective of this review paper is to explore natural resources-food nexus in the Mediterranean region by highlighting the environmental footprints of the current consumption and production patterns. Secondary data from different sources such as FAOSTAT, the World Bank, Water Footprint Network (WFN), and Global Footprint Network were used to analyze the situation in 21 Mediterranean countries".

Therefore, in addition to the traditional indicators of land use efficiency, it is necessary to study environmental losses, pollution, health and population's living standard because of agricultural activity and diet.

The impact of natural and climatic conditions upon the level of agricultural land use is a poorly predicted and uncontrolled process. Inter-Governmental Panel on Climate Change has shown that the earth temperature has increased by 0.74 degrees $C$ between 1906 and 2005 due to increase in anthropogenic emissions of greenhouse gases. By the end of this century, temperature increase is likely to be $1.8-4.0$ degrees C. This would lead to more frequent hot extremes, floods, droughts, cyclones and gradual recession of glaciers, which in turn would result in greater instability in food production (Aggarwal, 2008).
The abovementioned risks can be monitored through the "emergency" block.

Some scientists suggest the usage of intensive technologies of land use in the context of issue of planet's population increase and in terms of sufficient food provision.

Lal (2000) indicates that: "Enhancing food production would necessitate adoption ofland saving technologies through agricultural intensification on prime agricultural land, conversion of marginal lands to other appropriate land uses, and restoration of degraded lands and ecosystems. Soil-specific technologies for agricultural intensification will have to be developed, fine-tuned, and adopted. These technologies will address the issue of (i) enhancing soil structure, (ii) increasing nutrient use efficiency through integrated nutrient management and strengthening nutrient recycling mechanisms, (iii) conserving soil and water through residue management and adoption ofconservation tillage, (iv) improving water use efficiency through development and adoption of efficient methods of water harvesting, recycling and irrigation, and (v) increasing cropping intensity".

So, on the one hand, it is about increasing the level of land use intensity, and on the other, the authors emphasize the need to improve such technologies in order to protect soil, water and other natural resources. The same opinion is held by Chartres and Noble (2015) "Given the current pressures on natural resources, this will have to be achieved by some form of agricultural intensification that causes less environmental impact. Therefore, it is not just intensification of agriculture, but 'sustainable intensification' that must be at the forefront of the paradigm shift".

Therefore, the level of land use intensity and technological level are important indicators while studying the sustainability of agricultural land use.

Despite the high level of economic efficiency resulting from land use intensification, we cannot consider such an approach as an acceptable one at this stage of society's development. "On the negative side, intensification of agriculture in many parts of the world has resulted in salinization of irrigated lands in the drier regions and the loss of forest vegetation in the humid tropics" (Juo and Wilding, 2001).

Taking into account the conclusions of Lal (2015) about the fact that "Soil degradation, characterized 
by decline in quality and decrease in ecosystem goods and services, is a major constraint to achieving the required increase in agricultural production", it is reasonable to include indicators, which depict structural shifts, to the group of sustainability indicators of agricultural land use.

We also support the position of Tscharntke et al. (Tscharntke et al., 2012), who states "Under the current scenario of rapid human population increase, achieving efficient and productive agricultural land use while conserving biodiversity is a global challenge". The assessment of these factors' impact can be determined through indicators reflecting the protection of ecosystem functions and biological diversity.

Therefore, the study of monitoring the sustainability of agricultural land use, understanding the concept proposed by the UN as a sustainable development, is conducted by a narrow circle of scientists (Marada et al., 2012; Smith and McDonald, 1998). At the same time research is concentrated mainly in one of the areas: economic (Hreshchuk, 2019; Jansen, 2005), environmental (Turcekova et al., 2015; Gutierrez et al., 2017), social (Huaranca et al., 2019; Obando, 2018; Taylor, 2001). And even these studies are mostly limited by the experience of individual regions without comparisons with the results of agrarian reforms and agricultural policies of other countries, which significantly narrows the possibilities of using their positive practices.

In recent years studies assessing the impact of the level of agricultural land use on the state of food security have become especially relevant.

Integrated and systematic studies in terms of monitoring the sustainability of agricultural land use in Ukraine and the post-socialist countries have not been conducted. In addition it should be noted that there are differences in the indicators paid attention to in the EU and Ukraine, which does not allow for comparisons. This necessitated this study.

The hypothesis of our study is that there are significant differences in the achieved level of sustainability of agricultural land use in the EU Member States.

The purpose of our study is to identify a relevant set of indicators to assess the level of sustainability of agricultural land use development and the changes that happened in post-socialist camp's EU Member States for the period of 2005-2013.

\section{Materials and methods}

So, due to the international experience and the national research on this issue, in our opinion, it is advisable to use the methodological approaches:

- the construction of the indicators system, each of them reflects some aspects of the land use sustainability at the macro level (according to the specific issues);

- the construction of the integral indicator for comparing the countries' land use sustainability.

The first approach to the construction of indicators of sustainability is based on the construction of a system of indicators that can reflect some aspects of sustainability - environmental, economic, social and others. Compared to the integral indicators of sustainability, this approach is more widely spread. However, as it was already noted, there is no universally accepted and well-reasoned integral indicator for evaluating the effectiveness of the transition to sustainability in the world. In this context, the emphasis is on the construction of the system of indicators. It is advisable to have a limited number of indicators that are closely connected with the development of the macroeconomic policy priorities system. For example, the system of 100-150 indicators is hardly suitable for people who make decisions in the executive and legislative power structures. For this purpose the selection of the most important indicators for a particular purpose is made. Almost all international organizations and most countries followed this way in the development of "core indicators".

The use of the basic list of indicators is a necessary condition for the initial phase of creating a national system of indicators of sustainability. It should be kept in mind that indicators do not always answer the question of stability or instability of the processes. The answer to this question can be received only after the correct interpretation of the results.

There are two groups of indicators: gross natural and specific indicators. The first group of indicators is characterized by the natural or "specific-natural" expression, the second one is characterized by the "natural-cost" expression. The gross indicators are better suited for the analysis 
of the current environmental situation, the degree of its favorability for humans and the environment, the level and magnitude of effects on nature, the harm to health, and others. These indicators are easy to apply for limited areas, the regional analysis. On the other hand, the specific indicators of the nature capacity, the specific contaminants are more suited for the assessment of the structural and technological trends, the changes in the economic structure. They are also useful for the forecasting of the economic development, the changes of the actions for the environment and the changes of the environmental situation for the future. As the experience of our country in the 1990-s shows, analyzing one environmental problem the indicators may have the opposite dynamics (eg, the gross water pollution decreased, but specific pollution increased).

It is necessary to determinate of the indicators system of the agricultural land use sustainability that reflects the situation at the macro level in the best way.

The construction of the integral indicator to compare the countries' land use sustainability:

- the measurement of the partial (individual) indicators in one dimension (in a single scale) in relative values - the so-called method of indicators coagulation;

- the selection of partial indicators, which have the homogeneous effect (positive or negative) of increasing the numeric value;

- weighting (scoring) of the importance of each component.

For the adequate evaluation of the agricultural land use sustainability to compare the countries and to rank them in order to reduce their total capacity it is necessary:

- to prove the assessment criteria (they should be information available, simple or calculations, the numberof them should be not many, but they have as much $\mathrm{s}$ possible to describe the development of the land use);

- to develop a methodology for calculating the integrated indicators that sorting by different methods do not significantly affect the position in the ranking. In addition, it should be quite simple and clear, but partial indicators obtained in the calculation of integral indicators should not be just relative coefficients but still have economic content.
The information base for the research consisted of legislations, regulatory acts and program documents of the governmental authorities of Ukraine and the United States, official materials of the Cabinet of Ministers of Ukraine, methodological and statistical data of the National Statistical Office of the Russian Federation as well as data of respective bodies and establishments of other countries, scientific information from Internet (the results of the international organizations and the FAO's researches), and the results of the author's own studies.

The sustainability of the agricultural land use analysis is performed by the author's method in Ukraine and in the countries of the post-socialist camp, which are now the countries of the EU. This approach is applied for three reasons:

- firstly, a comparative analysis is always more objective;

- $\quad$ secondly, for comparison the former socialist countries were chosen, as they had similar to Ukraine economic, political and social problems after the collapse of the USSR;

- thirdly, the study group is only current EU members, as Ukraine is also seeking the membership in the European Union.

The following abbreviations are used in tables and figures (according to NANPP):

Lithuania - LT, Bulgaria - BG, Czech Republic - CZ, Poland - PL, Croatia - HR, Slovakia - SK, Estonia - EE, Latvia - LV, Romania - RO, Ukraine - UA, Slovenia - SI.

The system of indicators and criteria's approaches to the agricultural land use sustainability assessment are provided in Figure 3.

The economic methods and calculation methods are given below.

Methodology and methods of calculating the basic indicators of the agricultural land use sustainability proposed for the use at the macro level (according to the specific problems)

We have developed an appropriate system based on the following fundamental methodological approaches:

1) the indicators of sustainability must meet the following basic criteria: to combine environmental, social and economic aspects; to be clear and have unambiguous interpretation for those who make decisions; to have a quantitative expression; to be 
based on the existing system of the national statistics and not to require significant investments to gather information and calculations; to be representative for the interregional comparisons; to be able to assess in the time dynamics; to have a limited number;

2) the classification of the indicators is carried out according to the specific issues. The indicators are constructed in the way to give a quantitative description of the selected issues, based only on the state statistics database.

A very "compressed" system of the basic indicators of the agricultural land use sustainability at the macro level is developed on the basis of the defined criteria. This system is recommended for the macroeconomic government programs and national action plans (Table 1).

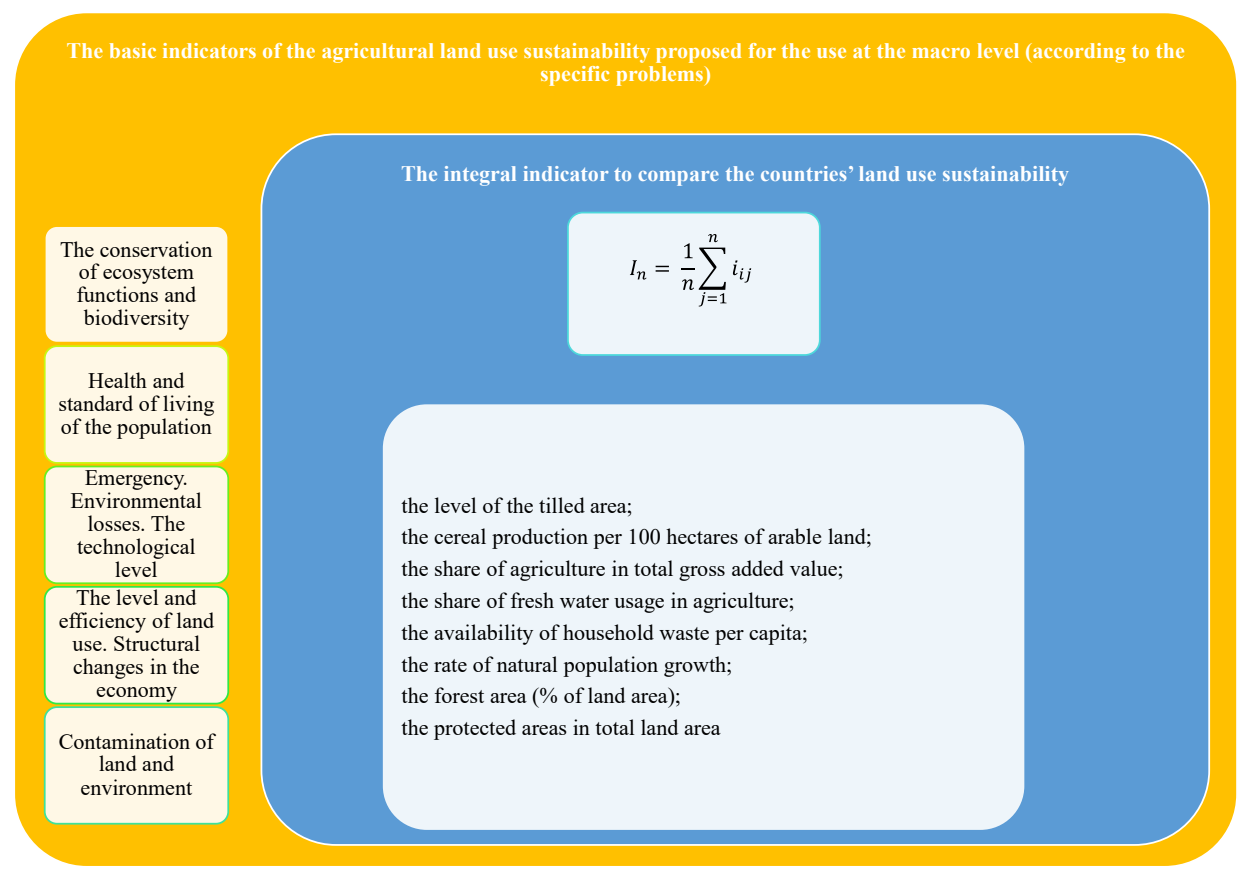

Note: $I_{n}$ - the integral indicator to compare the countries' agricultural land use stability; $n$ - the number of indicators (partial criteria).

Source: own work

Figure 3: The methodological approaches to the agricultural land use sustainability assessment.

\begin{tabular}{|c|c|}
\hline Problems & Indicators \\
\hline \multirow{6}{*}{$\begin{array}{l}\text { The level and efficiency } \\
\text { of the land use }\end{array}$} & 1.1. The degree of the land resources development, $\%$ \\
\hline & 1.2. The level of the tilled area, $\%$ \\
\hline & 1.3. The yield of grain, centners per 1 ha \\
\hline & 1.4. Cereal production per 100 hectares of arable land, tons \\
\hline & $\begin{array}{l}\text { 1.5. Gross agricultural output per } 100 \text { hectares of agricultural land, thousands of units } \\
\text { of national currency }\end{array}$ \\
\hline & 1.6. The area of arable land per 100 persons of the population, ha \\
\hline \multirow{2}{*}{$\begin{array}{l}\text { Structural changes } \\
\text { in the economy }\end{array}$} & 2.1. The share of agriculture in total gross added value, $\%$ \\
\hline & 2.2. The share of urban population in country's total population, $\%$ \\
\hline Environmental losses & 3.1. The share of fresh water usage in agriculture, $\%$ \\
\hline \multirow{2}{*}{ Emergency } & 4.1. Number of fires \\
\hline & 4.2. The area of forest land traversed by fires, ha \\
\hline \multirow{2}{*}{$\begin{array}{l}\text { Contamination of land } \\
\text { and environment }\end{array}$} & 5.1. The flow of sulfur oxide into the atmosphere per capita, $\mathrm{kg}$ \\
\hline & 5.2. The availability of household waste per capita, $\mathrm{kg}$ \\
\hline
\end{tabular}

Source: own work

Table 1: The basic indicators of the agricultural land use sustainability proposed for the use at the macro level (to be continued). 


\begin{tabular}{|c|c|}
\hline Problems & Indicators \\
\hline The technological level & 6.1. The adding of the mineral fertilizers per 1 ha of arable land, $\mathrm{kg}$ \\
\hline \multirow{8}{*}{$\begin{array}{l}\text { Health and standard of living } \\
\text { of the population }\end{array}$} & 7.1. The rate of natural population growth \\
\hline & 7.2. Gross agricultural output per capita, national currency units \\
\hline & 7.3. The index of income concentration (Gini coefficient), $\%$ \\
\hline & 7.4. The employment rate of the population, $\%$ \\
\hline & 7.5. The average annual per capita consumption: \\
\hline & 7.5.1. Calories, kilocalories \\
\hline & 7.5.2 Proteins, $g$ \\
\hline & 7.5.3 Fats, $\mathrm{g}$ \\
\hline \multirow{4}{*}{$\begin{array}{l}\text { The conservation } \\
\text { of ecosystem functions } \\
\text { and biodiversity }\end{array}$} & 8.1. The area of the forest fund, thous. ha \\
\hline & 8.2. The forest area ( $\%$ of land area), $\%$ \\
\hline & 8.3. The area of the protected areas, thous. ha \\
\hline & 8.4. The protected areas in total land area, $\%$ \\
\hline
\end{tabular}

Source: own work

Table 1: The basic indicators of the agricultural land use sustainability proposed for the use at the macro level (continuation).

The economic content of the indicators (calculation methodology) used in this study is described in Annex 1.

Methodology and methods of calculating the integral indicator to compare the countries' land use sustainability

The partial set of criteria, in our point of view, should include the following parameters:

- $\quad$ the level of the tilled area;

- the cereal production per 100 hectares of arable land;

- the share of agriculture in total gross added value;

- the share of fresh water usage in agriculture;

- the availability of household waste per capita;

- the rate of natural population growth;

- $\quad$ the forest area ( $\%$ of land area);

- $\quad$ the protected areas in total land area.

For the integral indicator only those baseline indicators from each block were chosen the impact of which was considered as decisive and that is why weighting factors wern't set for them because they equal in actual impact. The selected indicators reflect all blocks of basic indicators of sustainability of agricultural land use, proposed for use at the macro level. Exceptions are blocks 4 and 6 . Indicators of block 4 are not included for a number of reasons: first, the block lacks partial indicators that can be comparable and commensurate with other indicators; secondly, the forest cover of the territory is directly related to the indicators of Unit 4, and this indicator is included in the list of partial indicators of the integrated index for assessing the sustainability of agricultural land use. Application of mineral fertilizers per 1 ha of arable land (indicator 6 of block) was not included in the list of partial indicators in determining the integral index for assessing the sustainability of agricultural land use, as this indicator is representative only in dynamics and compared to regulatory data, which have significant differences for different soils and production technologies: it is not possible to establish a single base for all countries to calculate the rating.

The formula of the agricultural land use sustainability assessment is the following:

$I_{i}=\frac{1}{n} \sum_{j=1}^{n} i_{i j}$,

where $I_{n}$ - the integral indicator to compare the countries' agricultural land use stability; $n$ - the number of indicators (partial criteria).

The calculation of partial criteria (indices) is made by the formula:

- for the $j-s$ criteria, the quantitative growth of which positively affects the level of the country's development:

$$
i_{i j}=\frac{f_{i j}}{\max _{i} f_{j}},
$$

- for the $j-s$ criteria, the quantitative growth of which negatively affects the level of the country's development:

$$
i_{i j}=\frac{\min _{i} f_{j}}{f_{i j}},
$$


where $i_{i j}$ - the partial index of the $i$ rural area (district) development for the certain period; $f_{i j}$ - the value of the $j$ partial indicator (criterion) for the $i$ country; maxi $f_{j}$ - the maximum value of the $j$ partial indicator for all $i$ countries; mini $f_{j}$ - the minimum value of the $j$ partial indicator for all $i$ countries.

\section{Results and discussion}

1. The agricultural land use sustainability assessment according to the system of indicators, each of them reflects some aspects of the land use sustainability at the macro level (according to the specific problems)

The system of indicators is based on the structure of "problems-indicators", but, unlike the international structures of indicators, environmental, economic and social problems, which should reflect indicators are given in the "problems". 26 basic ecological and economic indicators and their modifications, quantitative importance and dynamics are given in Table 2.

For the agriculture in Ukraine compared to other countries of the post-socialist camp the high degree of the development of the land resources and the inadequate (on this background) reduction of the agriculture share in the total gross added value is extremely important. Moreover, the volume of the gross agricultural output per 100 hectares of farmland (in the national currency) increases.

The grain yield indicator shows the efficiency (more precisely, inefficiency) of this approach. Ukraine ranks the sixth place according to this indicator. However, in Ukraine there is the highest rate of grain production per 100 hectares of arable land.

\begin{tabular}{|c|c|c|c|c|c|c|c|c|c|c|c|}
\hline Indicators & BG & LV & LT & PL & RO & SK & SI & HR & $\mathrm{CZ}$ & EE & UA \\
\hline \multicolumn{12}{|c|}{ The first block. The level and efficiency of the land use } \\
\hline \multirow{2}{*}{ 1.1. The degree of the land resources development, $\%$} & 48 & 28 & 45 & 52 & 62 & 40 & 25 & 22 & 55 & 21 & 61 \\
\hline & 46 & 30 & 46 & 47 & 60 & 40 & 24 & 23 & 55 & 23 & 69 \\
\hline \multirow{2}{*}{ 1.2. The level of the tilled area, $\%$} & 29 & 18 & 30 & 40 & 39 & 29 & 9 & 16 & 42 & 14 & 51 \\
\hline & 32 & 19 & 37 & 35 & 38 & 29 & 9 & 16 & 41 & 15 & 54 \\
\hline \multirow{2}{*}{ 1.3. The yield of grain, centners per 1 ha } & 33.7 & 28.0 & 28.9 & 32.2 & 33.1 & 44.7 & 59.4 & 55.8 & 46.9 & 26.7 & 26.0 \\
\hline & 44.2 & 33.6 & 36.2 & 37.7 & 38.4 & 44.7 & 45.9 & 54.4 & 52.1 & 30.9 & 39.9 \\
\hline \multirow{2}{*}{$\begin{array}{l}\text { 1.4. Cereal production per } 100 \text { hectares of arable land, } \\
\text { tons }\end{array}$} & 110 & 62 & 72 & 72 & 82 & 116 & 80 & 69 & 129 & 45 & 123 \\
\hline & 147 & 122 & 125 & 86 & 83 & 121 & 80 & 114 & 149 & 65 & 194 \\
\hline \multirow{2}{*}{$\begin{array}{l}\text { 1.5. Gross agricultural output per } 100 \text { hectares } \\
\text { of agricultural land, thousands of units of national } \\
\text { currency }\end{array}$} & 113 & 33 & 231 & 330 & 374 & $\ldots$ & $\ldots$ & $\ldots$ & 2970 & 969 & 250 \\
\hline & 121 & 64 & 209 & 535 & 539 & 163 & 534 & 1761 & 2588 & 101 & 681 \\
\hline \multirow{2}{*}{$\begin{array}{l}\text { 1.6. The area of arable land per } 100 \text { persons } \\
\text { of the population, ha }\end{array}$} & 41 & 50 & 58 & 32 & 42 & 26 & 9 & 20 & 31 & 42 & 67 \\
\hline & 48 & 59 & 79 & 28 & 44 & 26 & 8 & 21 & 30 & 48 & 78 \\
\hline \multicolumn{12}{|c|}{ The second block. Structural changes in the economy } \\
\hline \multirow{2}{*}{$\begin{array}{l}\text { 2.1. The share of agriculture in total gross added value, } \\
\%^{*}\end{array}$} & 10.9 & 4.1 & 6.2 & 5.1 & 14.3 & 3.9 & 2.6 & $\ldots$ & 3.3 & 4.2 & 10.9 \\
\hline & 5.4 & 4.9 & 4.0 & 3.6 & 7.5 & 3.2 & 2.6 & 4.7 & 2.1 & 3.6 & 9.9 \\
\hline \multirow{2}{*}{$\begin{array}{l}\text { 2.2. The share of urban population in country's total } \\
\text { population, } \%\end{array}$} & 70.6 & 68.0 & 67.5 & 61.5 & 53.2 & 55.6 & 50.5 & 56.4 & 73.6 & 68.7 & 67.9 \\
\hline & 73.3 & 66.6 & 66.6 & 60.6 & 54.2 & 53.9 & 49.8 & 58.4 & 73.1 & 67.7 & 69 \\
\hline \multicolumn{12}{|c|}{ The third block. Environmental losses } \\
\hline \multirow{2}{*}{ 3.1. The share of fresh water usage in agriculture, $\%$} & 19.0 & 13.0 & 7.0 & 16.2 & 23.2 & 1.8 & 1.3 & $\ldots$ & 2.6 & 0.2 & 2.4 \\
\hline & 16.0 & 13.0 & 3.0 & 10.0 & 17.0 & 3.0 & 0.0 & 1.0 & 2.0 & 1.8 & 1.5 \\
\hline \multicolumn{12}{|c|}{ The fourth block. Emergency } \\
\hline \multirow{2}{*}{ 4.1. Number of fires } & 241 & 365 & 301 & 12803 & 64 & 287 & 73 & 147 & 636 & 65 & 4223 \\
\hline & 408 & 422 & 123 & 4883 & 116 & 233 & 75 & 137 & $\ldots$ & 15 & 1113 \\
\hline \multirow{2}{*}{ 4.2. The area of forest land traversed by fires, ha } & 1458 & 120 & 51 & 7387 & 162 & 524 & 280 & 3135 & 227 & 87 & 2300 \\
\hline & 3314 & 217 & 25 & 1289 & 421 & 270 & 66 & 1999 & $\ldots$ & 79 & 400 \\
\hline
\end{tabular}

Note: * the data about the countries (except LV, LT and CZ) are given for 2003 and 2011; ** the data about LV, LT and RO are given for 2000 and 2008; *** the Quinta coefficient of funds value is given for Ukraine; **** the numerator contains the data for 2011

Source: developed by the author according to the State Statistics Service of Ukraine (2018); Federal State Statistics Service of Russian Federation (2015); National Statistical Committee of the Republic of Belarus (2015); Word data Center (2019)

Table 2: The agricultural land use sustainability assessment by the indicators proposed for use at the macro level (2005/2013). (to be continued). 


\begin{tabular}{|c|c|c|c|c|c|c|c|c|c|c|c|}
\hline Indicators & BG & LV & LT & PL & RO & SK & SI & HR & $\mathrm{CZ}$ & $\mathrm{EE}$ & UA \\
\hline \multicolumn{12}{|c|}{ The fifth block. Contamination of land and environment } \\
\hline \multirow{2}{*}{$\begin{array}{l}\text { 5.1. The flow of sulfur oxide into the atmosphere per } \\
\text { capita, } \mathrm{kg}^{* *}\end{array}$} & 113.9 & 5.0 & 12.0 & 33.2 & $\ldots$ & 16.5 & $\ldots$ & $\ldots$ & 21.4 & 55.9 & 24.8 \\
\hline & 108.8 & 1.2 & 10.0 & 22.1 & 25.8 & 10.8 & $\ldots$ & 6.3 & 15.0 & 30.6 & 31.2 \\
\hline \multirow{2}{*}{ 5.2. The availability of household waste per capita, $\mathrm{kg}$} & 588 & 320 & 387 & 319 & 383 & 273 & 494 & 336 & 289 & 433 & $\ldots$ \\
\hline & 432 & 312 & 433 & 297 & 272 & 304 & 414 & 404 & 307 & 293 & 260 \\
\hline \multicolumn{12}{|c|}{ The sixth block. The technological level } \\
\hline \multirow{2}{*}{$\begin{array}{l}\text { 6.1. The adding of the mineral fertilizers per } 1 \text { ha } \\
\text { of arable land, } \mathrm{kg}\end{array}$} & 74 & 68 & 98 & 162 & 51 & 81 & 330 & 295 & 90 & 61 & 18 \\
\hline & 136 & 100 & 84 & 202 & 56 & 112 & 267 & 235 & 127 & 83 & 46 \\
\hline \multicolumn{12}{|c|}{ The seventh block. Health and standard of living of the population } \\
\hline \multirow{2}{*}{ 7.1. The rate of natural population growth } & -5.4 & -4.9 & -3.9 & -0.1 & -1.9 & 0.2 & -0.3 & -2.1 & -0.5 & -2.2 & -7.6 \\
\hline & -5.2 & -4.0 & -3.9 & -0.5 & -3.5 & 0.5 & 0.8 & -2.4 & -0.2 & -1.3 & -3.5 \\
\hline \multirow{2}{*}{$\begin{array}{l}\text { 7.2. Gross agricultural output per capita, national } \\
\text { currency units }\end{array}$} & 488 & 166 & 1336 & 1088 & 1654 & $\ldots$ & $\ldots$ & $\ldots$ & 8898 & $\ldots$ & 2016 \\
\hline & 586 & 380 & 1648 & 1526 & 2369 & 421 & 437 & 3674 & 7762 & 482 & 7419 \\
\hline \multirow{2}{*}{$\begin{array}{l}\text { 7.3. The index of income concentration (Gini } \\
\text { coefficient), } \% * * *\end{array}$} & 29.2 & 33.6 & 31.9 & 34.1 & 31.0 & 25.8 & 28.4 & $\ldots$ & 25.4 & 37.2 & 3.6 \\
\hline & 34.3 & 36.0 & 32.6 & 32.8 & 27.3 & 26.6 & 24.9 & 33.6 & 26.4 & 32.7 & 3.4 \\
\hline \multirow{2}{*}{ 7.4. The employment rate of the population, $\%$} & 55.8 & 62.1 & 62.9 & 52.8 & 57.6 & 57.7 & 66.0 & 55.0 & 64.8 & 64.8 & 65.4 \\
\hline & 59.5 & 65.0 & 63.7 & 60.0 & 59.7 & 59.9 & 63.3 & 52.5 & 67.7 & 68.5 & 67.4 \\
\hline \multicolumn{12}{|l|}{ 7.5. The average annual per capita consumption $* * * *$ : } \\
\hline \multirow{2}{*}{ 7.5.1. Calories, kilocalories } & 2723 & 3149 & 3464 & 3371 & 3424 & 2841 & 3090 & 2979 & 3318 & 3171 & 2916 \\
\hline & 2877 & 3293 & 3463 & 3485 & 3363 & 2902 & 3173 & 3052 & 3292 & 3214 & 2969 \\
\hline \multirow{2}{*}{ 7.5.2. Proteins, $g$} & 78 & 86 & 120 & 99 & 109 & 74 & 99 & 78 & 99 & 92 & 86 \\
\hline & 84 & 97 & 124 & 102 & 105 & 74 & 99 & 82 & 91 & 96 & 90 \\
\hline \multirow{2}{*}{ 7.5.3. Fats, $g$} & 96 & 118 & 101 & 113 & 105 & 101 & 118 & 107 & 128 & 93 & 90 \\
\hline & 92 & 127 & 103 & 121 & 105 & 107 & 119 & 110 & 139 & 88 & 100 \\
\hline \multicolumn{12}{|c|}{ The eighth block. The conservation of ecosystem functions and biodiversity } \\
\hline \multirow{2}{*}{ 8.1. The area of the forest fund, thous. ha } & 3652 & 3056 & 2176 & 9192 & 6628 & 1929 & 1308 & 2135 & 2648 & 2366 & 10556 \\
\hline & 3845 & 3468 & 2284 & 9435 & 6951 & 1940 & 1271 & 2491 & 2667 & 2456 & 10624 \\
\hline \multirow{2}{*}{ 8.2. The forest area, $\%$} & 33.6 & 49.1 & 34.7 & 30.0 & 28.8 & 40.1 & 64.9 & 44.4 & 34.3 & 55.8 & 17.5 \\
\hline & 35.4 & 55.8 & 36.4 & 30.8 & 30.2 & 40.3 & 63.1 & 44.5 & 34.5 & 57.9 & 17.6 \\
\hline \multirow{2}{*}{ 8.3. The area of the protected areas, thous. ha } & 10234 & 12182 & 2945 & 68579 & 18826 & $\ldots$ & $\ldots$ & 4540 & 11785 & 15496 & 1057 \\
\hline & 41617 & 13181 & 11542 & 112295 & 46796 & 17664 & 11232 & 9090 & 17426 & 16289 & 1576 \\
\hline \multirow{2}{*}{ 8.4. The protected areas in total land area, $\%$} & 8.7 & 16.2 & 4.4 & 21.3 & 7.8 & $\ldots$ & $\ldots$ & 5.2 & 15.1 & 22.1 & 1.8 \\
\hline & 35.4 & 17.6 & 17.3 & 34.8 & 19.2 & 36.1 & 54.9 & 10.3 & 22.4 & 23.2 & 2.6 \\
\hline
\end{tabular}

Note: * the data about the countries (except LV, LT and CZ) are given for 2003 and 2011; ** the data about LV, LT and RO are given for 2000 and 2008; *** the Quinta coefficient of funds value is given for Ukraine; **** the numerator contains the data for 2011

Source: developed by the author according to the State Statistics Service of Ukraine (2018); Federal State Statistics Service of Russian Federation (2015); National Statistical Committee of the Republic of Belarus (2015); Word data Center (2019)

Table 2: The agricultural land use sustainability assessment by the indicators proposed for use at the macro level (2005/2013). (Continuation).

The change of the land provision indicator (the area of arable land per 100 persons of the population) is marked by the positive dynamics in Ukraine. However, comparing this indicator to the level of arable territory, which is the highest value in Ukraine, it is obvious that the positive trend is provided by the increasing of the arable land area with the decreasing of the population.

The global issues are reflected in the indicators of ecosystem functions saving and the conservation of biodiversity and the protection of land (the indicators are the following: the area of the forest fund and the protected areas, the forest area, the share of the protected areas in the total area).

According to the natural indicators of the given block of indicators, Ukraine ranks the first places among the post-socialist countries, but according to the relative indicators, it ranks the last places. Ukraine has the largest area of the forest fund and the lowest level of the forest cover; the share of the protected areas is less than $3 \%$, while in other countries it ranges from 10 to $55 \%$. Moreover, the area of the arable land in the postsocialist countries is in times less than the area 
of the protected areas, and in Ukraine - on the contrary.

The problem of the low technological level of production and the connected with it accidents and disasters, leading to environmental pollution is an extremely difficult problem for solving for the post-socialist camp countries (the indicators are the following: the share of the costs of fresh water in agriculture, the number of fires, the area of forest land traversed by fires, mineral fertilizers per 1 ha of arable land).

The problem of the economic evaluation of the pollution impact on the state of the soil is extremely relevant, as the European and Ukrainian studies showed. It is necessary for the executive and legislative bodies of power to pay more attention to the protection of land resources (the indicators are the following: the flow of sulfur dioxide into the atmosphere per capita; the availability of household waste per capita).

Among the post-socialist countries Ukraine ranks the eighth place according to the share of costs of fresh water in agriculture, but at the same time it ranks the second place according to the number of forest fires and the flow of sulfur dioxide into the atmosphere per capita, the fourth place according to the area of forest lands traversed by fires, and the last place according to the level of mineral fertilization.

Because of the environmental pollution and the decrease of the agriculture efficiency the problem of health and the living standards of population in Ukraine is identified (the indicators are the following: the rate of natural population growth, gross agricultural output per capita, the index of income concentration, the employment rate of the population, the average annual per capita consumption of calories, proteins and fats).

Ukraine compared to the post-socialist countries occupies the top positions according to the received gross agricultural output per capita (the second place), the level of employment (the third place) and the level of average calorie consumption (within the norms). However, the death rate in Ukraine exceeds the birth rate and fat consumption exceeds the protein consumption.

In turn, the changes in these indicators affect the structural changes in the ratio of rural and urban population: in Ukraine urbanization increases, while in Latvia, Lithuania, Poland, Slovakia, Slovenia and the Czech Republic the dynamics of the increasing of the proportion of rural population is positive.

According to the obtained data, the agricultural land use in Ukraine, as well as in the other post-socialist countries, has a positive dynamics by the majority of indicators, but has not reached the sustainability indicators yet. According to the six indicators in Ukraine, Latvia, Lithuania, Slovenia, Croatia and Estonia the negative dynamics of development is set. Poland and Slovakia have better results (the first one has 4 indicators with negative value growth and the second one has 5 indicators with negative value growth). Bulgaria and the Czech Republic have worse results (the first one has 8 indicators with negative value growth and the second one has 9 indicators with negative value growth). However, only 3 out of 25 indicators (cereal production per 100 hectares of arable land, the area of pro in the total area) set a positive trend for all the countries.

In the context of the separate blocks of indicators, different trends are set.

As for the block "The level and efficiency of the land use" the most indicators with negative growth rate are set for Latvia and Estonia (Figure 4). Ukraine together with Latvia, Slovenia, Croatia and the Czech Republic is in the group of countries in which the negative deviation of growth rates is determined by two indicators. The least negative deviations in the growth rates indicators for this block are set in Bulgaria (1 indicator) and Slovakia (there is no any negative deviation).

For such countries as Latvia, Lithuania, Croatia, Estonia and Ukraine, the problematic issue is the pace of dynamics of the development of the land resources and arable areas. The common thing for these countries is the positive dynamics of grain production per 100 hectares of arable land, though, the yield of grain in Slovenia and Croatia in dynamics decreased.

According to the block "Structural changes" only Latvia and Slovenia have positive dynamics of the indicators (Figure 5). The negative rate of the share of agriculture in total gross added value is set in 8 countries (Latvia and Slovenia are the exceptions), and most of all is in Romania and Bulgaria. The accelerated pace of urbanization can be seen in 4 countries (Bulgaria, Romania, Croatia and Ukraine). 


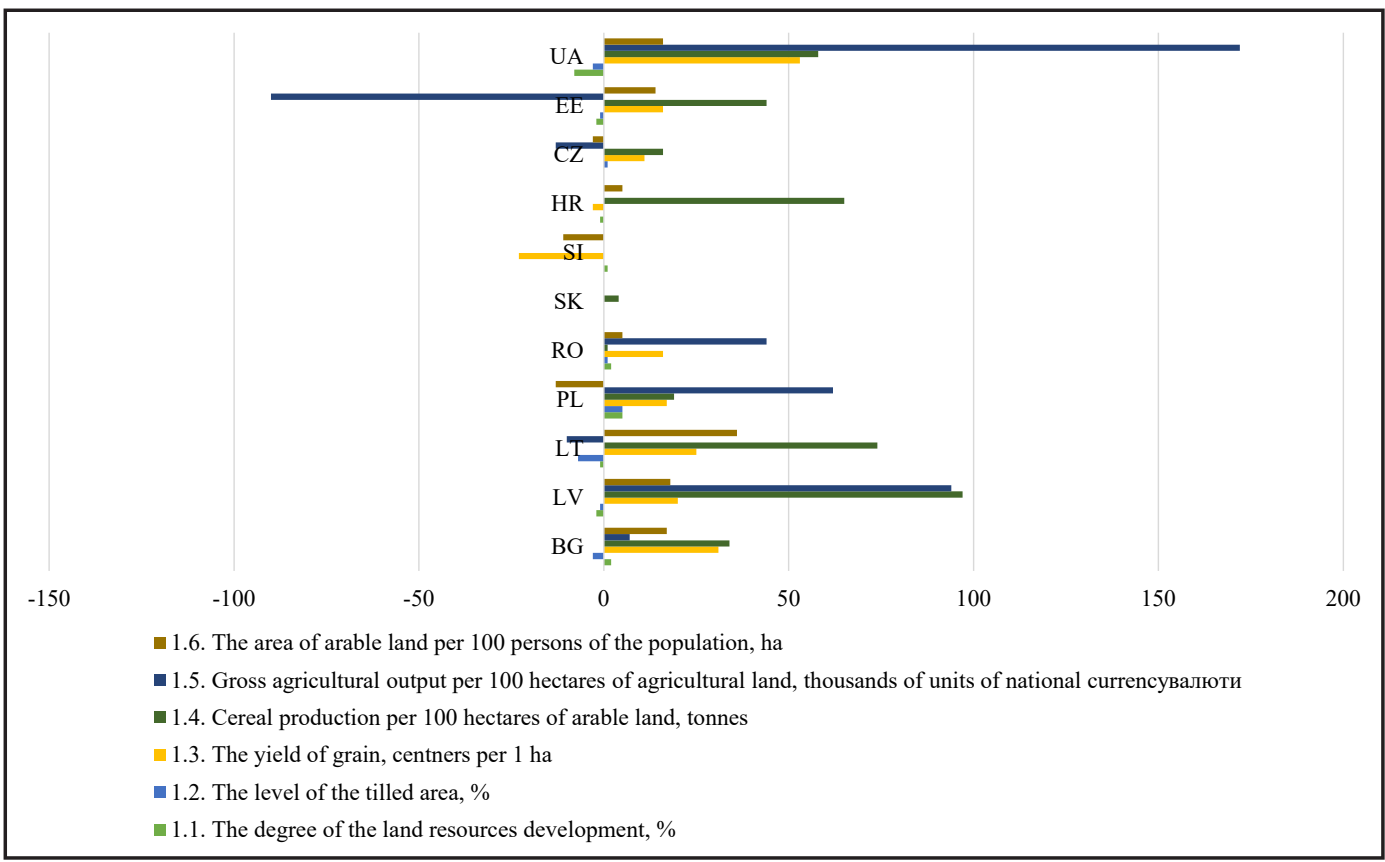

Source: developed by the author

Figure 4: The assessment of the dynamics of indicators of the agricultural land use sustainability according to the indicators of the block "The level and efficiency of the land use".

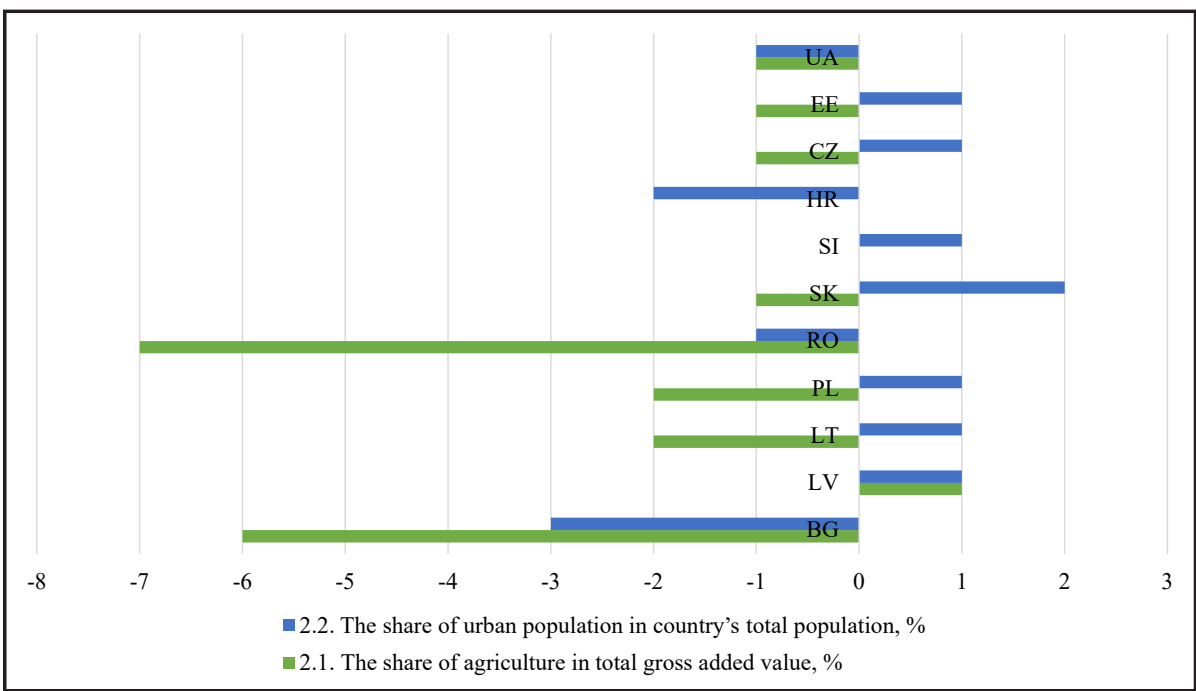

Source: developed by the author

Figure 5: The assessment of the dynamics of indicators of the agricultural land use sustainability according to the indicators of the block "Structural changes in the economy".

According to the block "Environmental losses", "Emergency" and "The technological level" the negative growth rates can be seen in all indicators, but most of all it is connected with the adding of the mineral fertilizers (Bulgaria, Latvia, Poland, Romania, Slovakia, the Czech Republic, Estonia and Ukraine) (Figure 6). On the other hand, such changes can be regarded as positive, contributing to the greening of production, as the growth rates of crops yield for most of these countries are positive. It should be noted that Bulgaria, Latvia and Romania have a very high growth rate of the number of fires and the area of forest land traversed by fires.

According to the block "Environmental pollution", Ukraine should be mentioned as the only country among the surveyed countries, which increased the flow of sulfur into the atmosphere per capita while reducing its number (Figure 7). 


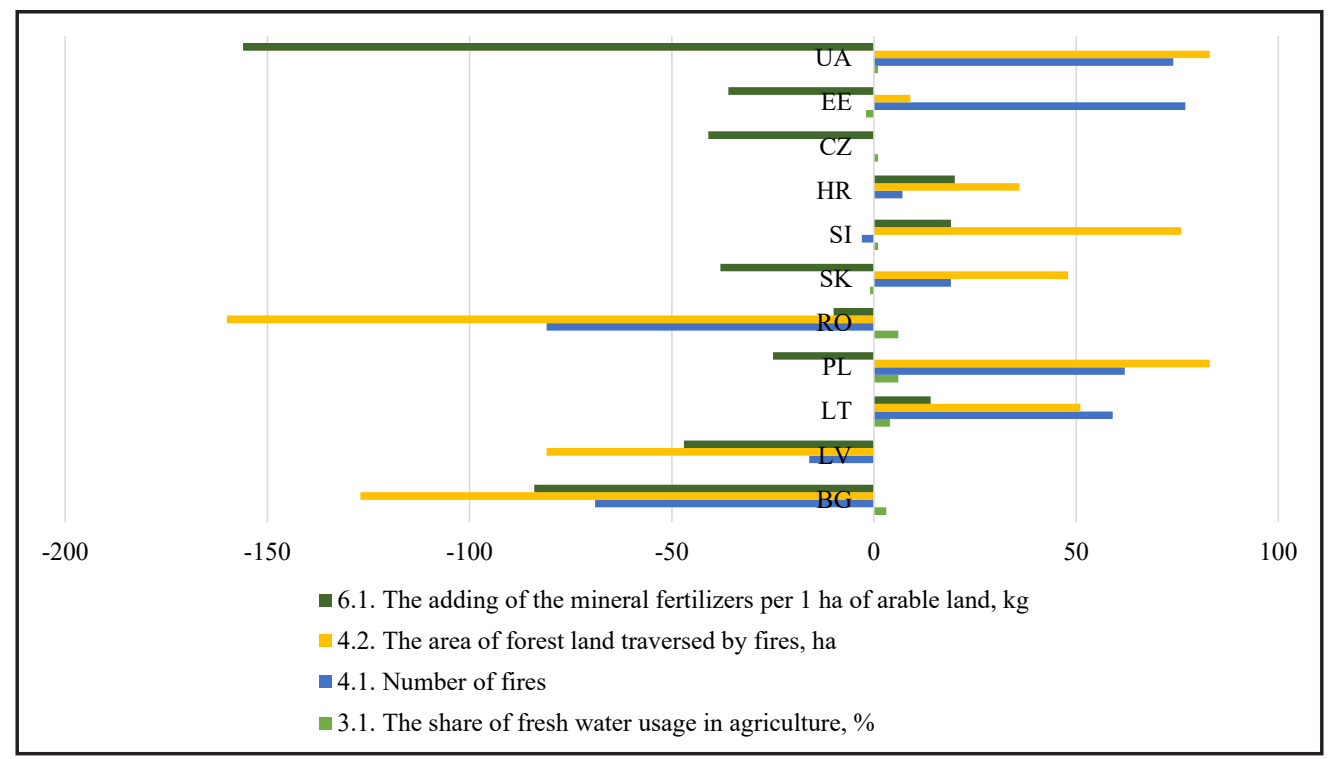

Source: developed by the author

Figure 6: The assessment of the dynamics of indicators of the agricultural land use sustainability according to the indicators of the blocks "Environmental losses", "Emergency" and "The technological level".

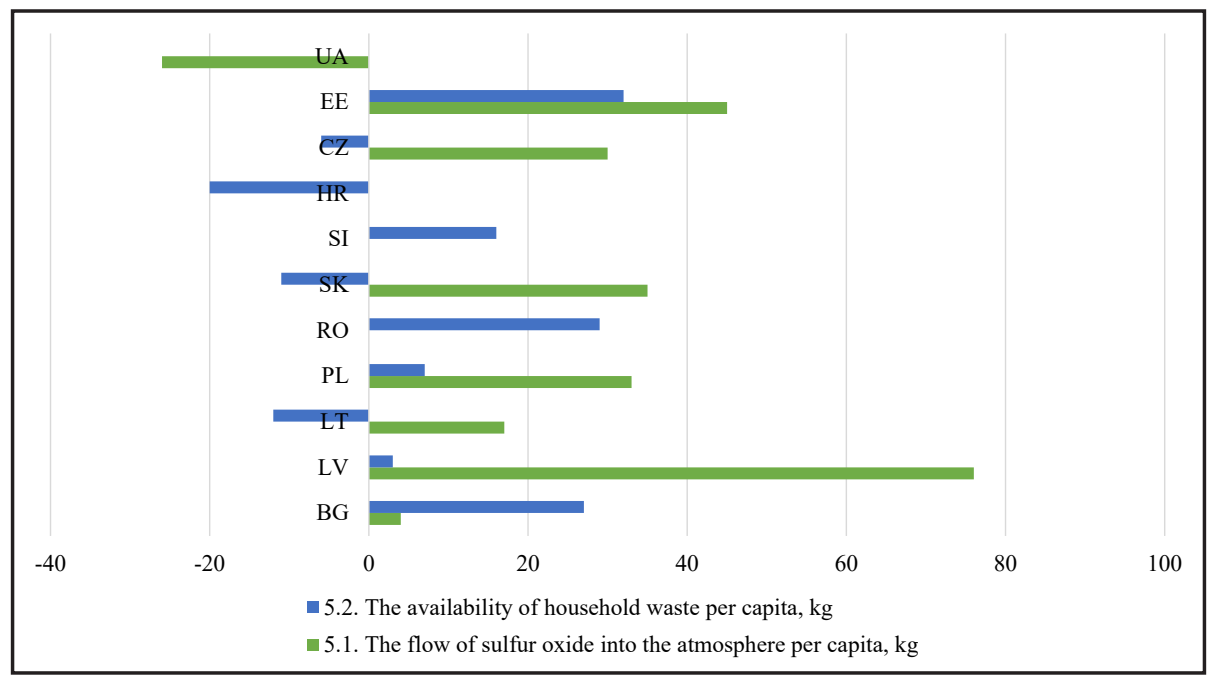

Source: developed by the author

Figure 7: The assessment of the dynamics of indicators of the agricultural land use sustainability according to the indicators of the block "Contamination of land and environment".

According to the block "Health and the living standards of the population", Ukraine is the only country which has the positive growth in all indicators (Figure 8). Another six countries (Latvia, Lithuania, Poland, Slovakia, Slovenia and Estonia) have negative trends only for one of the identified indicators. The highest growth rates of the negative values are set by the indicator of income inequality - in Bulgaria, Latvia, Lithuania, Romania and Croatia.
The top trends according to the studied indicators are set by the indicators of the block "The conservation of ecosystem functions and biodiversity» (Figure 9). Only in Slovenia the negative growth rates of the area of the forest funds and the forest area are found. However, the largest growth rates of the protected areas are set in Bulgaria and Lithuania. 


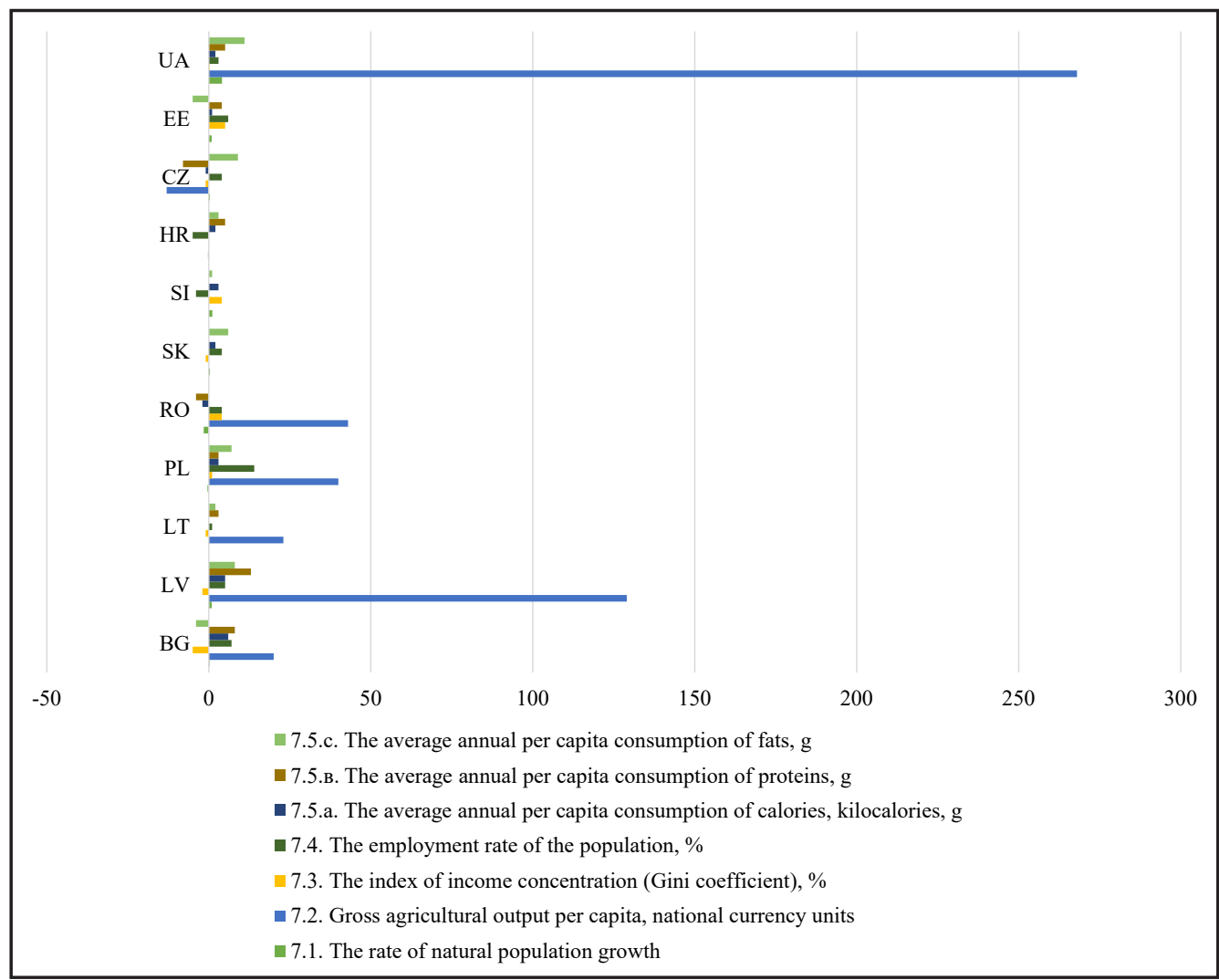

Source: developed by the author

Figure 8: The assessment of the dynamics of indicators of the agricultural land use sustainability according to the indicators of the blocks "Health and standard of living of the population".

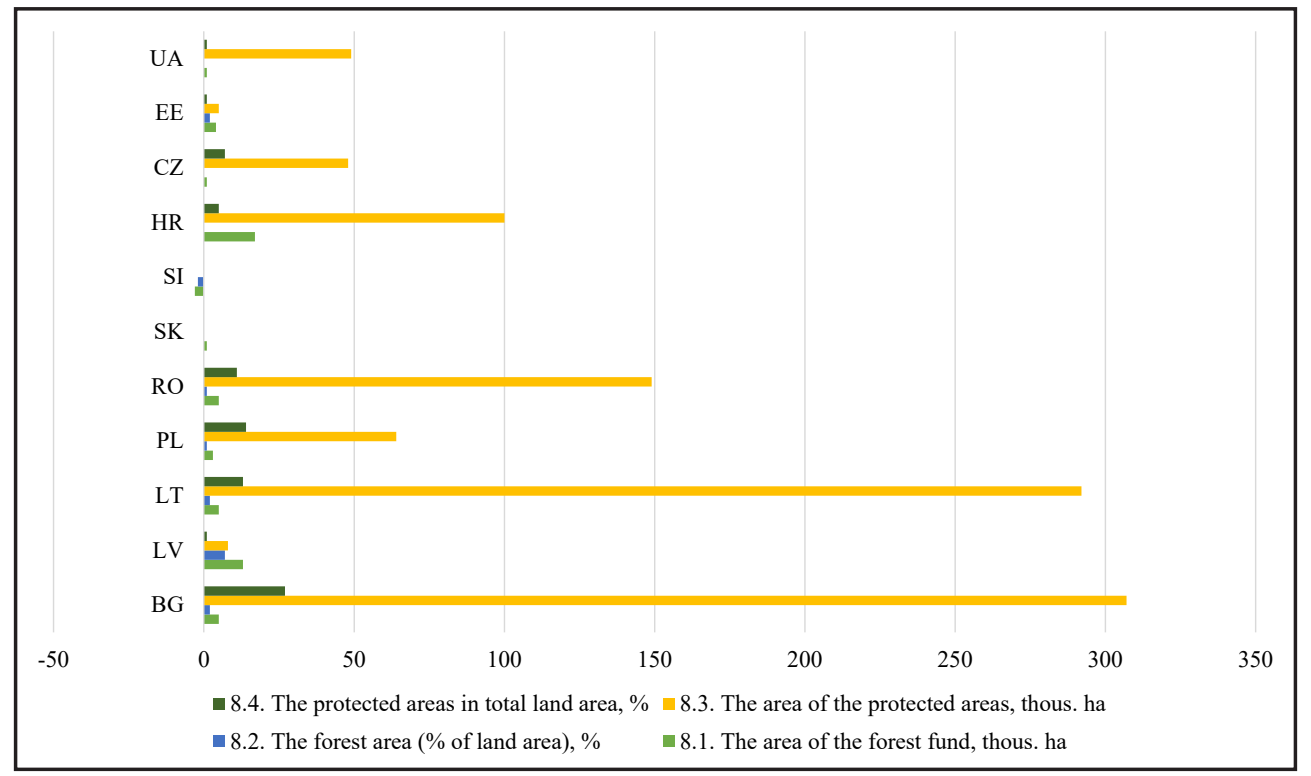

Source: developed by the author

Figure 9: The assessment of the dynamics of indicators of the agricultural land use sustainability according to the indicators of the block "The conservation of ecosystem functions and biodiversity".

Most indicators the dimension of which is allowed, we correlated with the data for 2005. As for some indicators because of the lack of the data the comparison was held for other periods:
- the share of agriculture in total gross added value - the data about the countries (except Latvia, Lithuania and the Czech Republic) are taken for 2003 and 2011; 
- $\quad$ the flow of sulfur oxide into the atmosphere per capita - the data about Latvia, Lithuania and Romania are taken for 2000 and 2008;

- the average annual per capita consumption - the data for 2011 are given in the numerator. According to the index of income concentration (Gini coefficient) - the Quinta coefficient of funds value is given for Ukraine, which is calculated according to the methodology for assessing the living standards and incomes of the population of Ukraine according to the official statistics.

\section{Calculating the integral indicator to compare the countries' land use sustainability}

According to the calculations in 2005, Estonia, the Czech Republic and Latvia got the first three places in the ranking (Figure 10).

Estonia had the highest share indices by two of the eight indicators: the share of the fresh water usage in agriculture and the share of the protected areas in the total area.

In the Czech Republic the value of three partial indicators exceeded 0.7: cereal production per 100 hectares of arable land; the availability of household wastes per capita; the level of employment.

In Latvia the value of three partial indicators exceeded 0.7: the availability of household wastes per capita; the level of employment; the forest area; the share of the protected areas in the total area.
Ukraine, Croatia and Lithuania got the last three places in the ranking. The main reason for such low indicators, common to these countries, is the low share of the protected areas in the total area. In addition, Ukraine and Lithuania have the high level of the share of the fresh water usage in agriculture.

Overall, the gap between the highest and lowest generalized indicator of the agricultural land use sustainability assessment in 2005 was 2.34 units (the value of the highest indicator exceeds the value of the lowest one by 1.7 times).

During the ten years the ranking table changed for all surveyed countries except Bulgaria. Five countries fell by ranking, including: Poland - by 1 position; Lithuania and Estonia - by 2 positions; the Czech Republic - by 5 positions; Romania - by 6 positions. Five countries increased by rating, including: Latvia and Croatia - by 1 position; Slovakia - by 3 positions; Slovenia - by 4 positions; Ukraine - by 7 positions.

In 2013, Estonia and Latvia retained its primacy in the ranking, and Slovenia got into the top three instead of the Czech Republic (Figure 11).

The distribution of places among these countries according to the partial indicators also changed. For example, Slovenia had the highest share indicators in four out of eight indicators: the level of the tilled area; the forest area; the share of the protected areas in the total area and the share of the fresh water usage

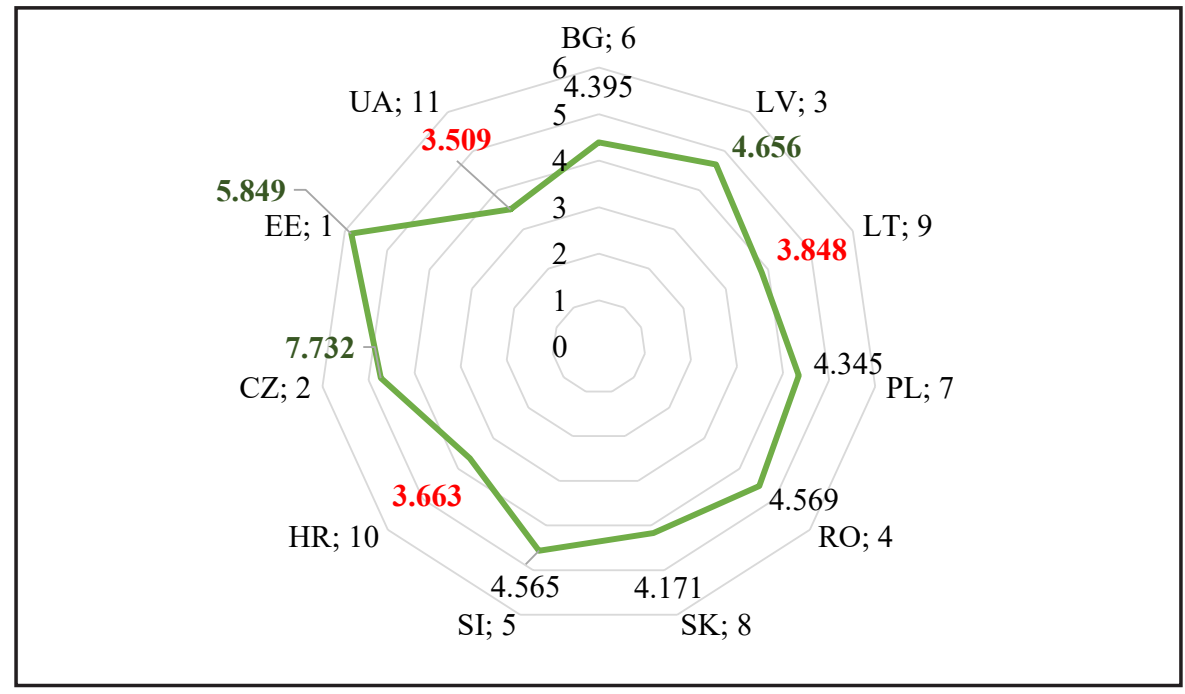

Source: developed by the author

Figure 10: The rating of the post-socialist countries according to the agricultural land use sustainability assessment in 2005 . 


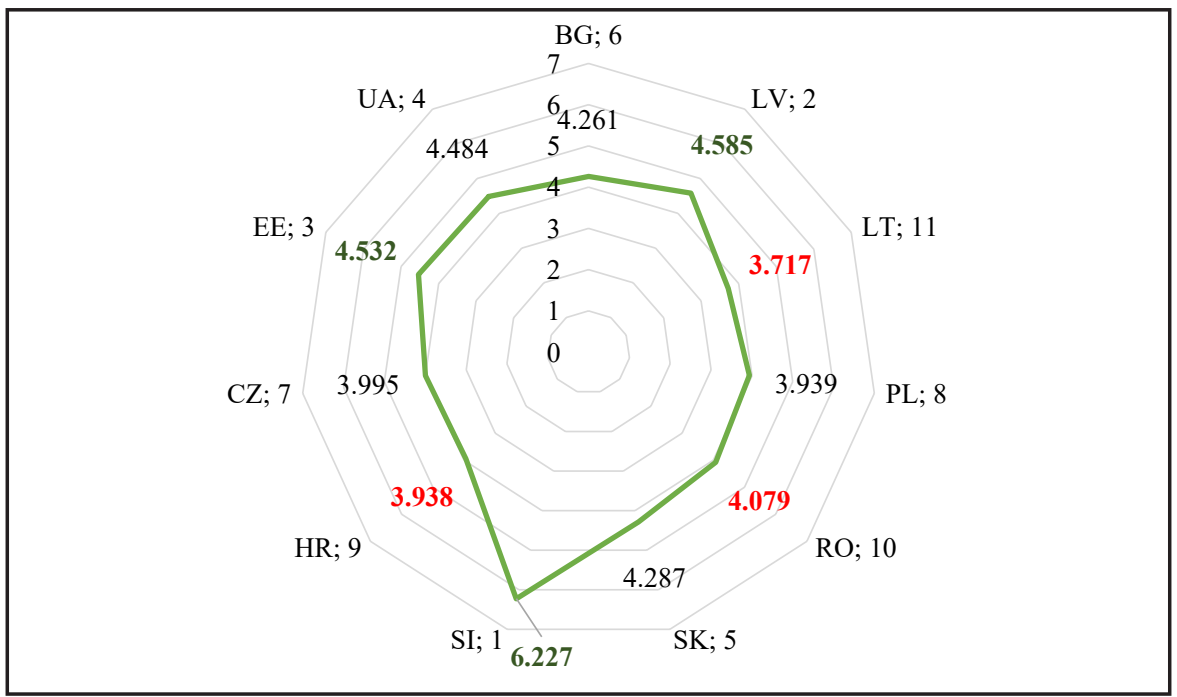

Source: developed by the author

Figure 11: The rating of the post-socialist countries according to the agricultural land use sustainability assessment in 2013

in agriculture, in which there was a significant increase (of 0.761 units).

In Estonia and Latvia according to the three partial indicators their value exceeded 0.7: the availability of the household wastes per capita; the level of employment and the forest areas.

Croatia, Lithuania and Romania took the last three places in the ranking instead of Ukraine. In Romania in 2013 compared to 2005 the value of five out of eight partial indicators decreased (cereal production per 100 hectares of arable land, the share of the fresh water usage in agriculture, the level of employment, the share of the protected areas in the total area, the share of agriculture in the total gross added value). In Ukraine during this period the values of four indicators significantly improved (cereal production per 100 hectares of arable land, the share of agriculture in total gross added value, the forest area, the availability of the household wastes per capita).

The main reason for such poor indicators, common for these countries, also changed. If in 2003 it was a low proportion of the protected areas in the total area, in 2013 it was a high proportion of the fresh water usage in agriculture. Besides, Lithuania and Romania had a high level of the tilled area.

Overall, the gap between the highest and lowest general indicator of the agricultural land use sustainability assessment in 2013 was 2.51 units (the value of the highest indicator exceeds the value of the lowest indicator by 1.7 times).
Similar approaches to assessing the sustainability of agricultural land use, based on a system of indicators describing the economic, social and environmental results of land use, have been introduced by Marada et al. (2012) and Smith and McDonald (1998).

Marada et al. (2012) presents the importance and possibilities for assessing the sustainability of farming on arable land. The methodology SAGROS was developed at the Mendel University in Brno to provide tool for these assessments in the Czech conditions. It covers environmental as well as economic and social dimension of sustainability using set of 21 main and 32 partial indicators. Final result is presented by overview of normalised values in radial graph to make identification of week points of farm management easier. Unfortunately, this method was used to assess particular agricultural enterprise in the period 2009-2011. At the same time, the study confirms the representativeness of the assessment of the sustainability of agricultural land use according to our proposed method at the macro level, which has already been tested at the micro level.

Smith and McDonald (1998) review the current state of knowledge in defining sustainable agriculture within the broader sphere of sustainable development. They conclude that agricultural sustainability encompasses biophysical, economic and social factors operating at the field, farm, watershed, regional and national scales. 
The immediate challenge is to determine what are sustainable agricultural uses before they are implemented - at the planning stage. The final section outlines a framework within which current land evaluation, environmental impact and strategic environmental assessment approaches to land use planning may be extended, and argues that these approaches must include, from the beginning, sustainability criteria.

For the first time, a comprehensive study assessing the level of sustainability of agricultural land use in the countries of the post-socialist camp, which are full members of the EU, as well as Ukraine, was published in 1999. Countries reports on the current environmental situation in agriculture were presented at the Central and Eastern European Sustainable Agriculture Network seminar (FAO, 1999). This document best reflects the objectives of our study in terms of content and list of countries studied. All reports have the same structure, which simplifies their comparative assessment, and are built on the principle of identified problems, which corresponds to the first methodological approach of our study. On the other hand, the reports are more descriptive, which makes it impossible to compare them quantitatively by measuring the indicators according to the second methodological approach proposed in our study. At the same time, the conclusions declared in the report are in full agreement with the conclusions of our study, in particular, obtained by the first methodological approach.

The next similar study was conducted in 2005, the results of which were published Agriculture and environment in EU-15 - the IRENA indicator report (EEA, 2005). The project covered $15 \mathrm{EU}$ Member States in 2002 and aimed to develop a system of agri-environmental indicators to monitor progress towards integrating environmental concerns into the CAP. The report covers the period from 1990 to 2000 on 42 indicators. The evaluation was performed for each indicator on a score system from 0 to 2 , which generally gave a result in the range from 6 to 19 points: 13 indicators are in the range of 15 points and above, which characterizes them as positive; 28 indicators are in the range from 8 to 14 points and are characterized as potentially positive; only 1 low potential indicator (ground water levels - IRENA 31). Thus, this study is more consistent with the first methodological approach proposed by us in the article. However, the conclusions of the report are not detailed for specific countries, and the recommendations are general for all countries studied, so they can not be compared with the results obtained in our study, although the list of indicators is significant in number.

The latest report on a large-scale study of the sustainability of agricultural land use on identified issues in EU member states was published in 2014 (Keenleyside et al., 2014). Unlike previous documents, this study focuses on assessing the results achieved through the implementation of the Common Agricultural Policy. This factfinding study provides recommendations for future EU policy on the development of High Nature Value farmland. All the digital information in the study is given in aggregate for the $27 \mathrm{EU}$ member states in 2014, so it is impossible to compare the results of the report with the research of the article, but the main recommendations of the report are consistent with the conclusions of the article in the economic block.

Further research focuses mainly on the ecological component of agricultural land use. This approach may be due to the fact that social issues related to land use are not as critical for EU member states as for Ukraine. In particular, a report was published in 2014 that includes aspects of data on the various relationships between agriculture and the environment (Elbersen et al., 2014). The report describes data gaps in the field of ecologically valuable pastures and lands, provides examples of best practices in agricultural land use and practical recommendations for optimal design and management of coastal buffer zones. The conclusions of the report coincide with the conclusions of the study in terms of proposals for solving environmental problems, which is explained by the purpose of the report. However, the proposals and recommendations presented in the report are mostly generalized without country detail.

A number of other reports were published before 2014, but the conclusions cannot be compared with those obtained in the article, as the reports either covered a narrow range of research problems or considered a set of problems in the context of a single country or 2-3 countries.

After 2014, no studies similar in content and coverage to countries were conducted.

Summarizing the above, in general, for all studied countries, the following three criteria for sustainable land development in the long-term perspective could be identified.

First, for land resources, their number or ability 
to produce biomass must, at least, not decrease over time, that is to ensure a simple mode of reproduction. This means preserving the area of the most valuable agricultural land or - in the case of reducing their area - maintaining (increasing) the level of agricultural production, forage potential of land for farm animals, etc.

Secondly, it is necessary to develop and implement systems of low-waste and resource-saving technologies, which will significantly reduce their workload per person or unit of area.

Third, pollution of land resources (both total and by type) in the future should not exceed its current level, it is necessary to predict the possibility of minimizing pollution of socially and economically acceptable level (unrealistic to expect "zero" pollution).

This approach to determining the main criteria is based on the fact that land belongs to the category of inexhaustible renewable resources. Thus changes in economy of land resources should be based on methodological principles of modern resource science:

1) inexhaustible resources do not exist. On the Earth in relation to human activity there is an inviolable law of exhaustion of all natural resources. Even sources of cosmic energy - solar radiation and gravitational (tidal) energy can be limited in time due to changes in their quality on Earth under the influence of anthropogenic actions;

2) exhaustibility of land resources depends on the level of their renewable. The amount of land extraction that exceeds the amount of their self-restoration, in fact, puts these resources in the category of non-renewable. Excess of extraction over recovery, even short-term, is dangerous not so much by reduction of stocks of resources, how many disturbance of natural regulatory mechanisms of recovery;

3) no research or economic activity can be qualified as the reproduction of land resources. As a rule, it is only a matter of expanding the front of their operation. In the best and very special case man can only partially restore the previously impaired ability of natural mechanisms to recover;

4) large-scale exploitation of land resources on the scale of the evolution of the biosphere on Earth can be maintained only for a relatively short time, limited by the impending global environmental crisis;

5) the laws of nature exclude ownership of ecosphere resources, including land. Resources should not belong to individuals, groups of people or states. They belong to all mankind as a whole, including all future generations of people. Therefore, the ownership of land resources established by human laws is always relative and can never be complete. Land ownership, which harms nature and through it man, must be excluded;

6) land resources used by man must be reproduced, restored both quantitatively and qualitatively. This means the qualitative characteristics of the soil. Expecting natural recovery in conditions of violation of the environmental regulatory function of the biosphere in most cases are not justified;

The implementation of these principles essentially means the application of a high biosphere environmental tax on land resources, which will ultimately lead to an increase in the cost of the entire resource base of the economy and, accordingly: general quantitative restrictions on the extraction of agricultural land resources; the need for fuller use of useful components from raw materials; stimulation of all means and technologies that allow to reduce the volume of land resources in the process of production and consumption; the need to find technologies for agricultural production that would replace the use of land resources with new, cheaper and highly environmental.

All these criteria must be taken into account in the process of developing the concept of sustainable development. Taking into account certain criteria will preserve the environment for future generations and will not worsen the ecological conditions of their habitat.

\section{Conclusion}

The generalization of the foreign and domestic methodological experience to develop the sustainability indicators sets the following trends:

- the increase of the number of indicators used to assess sustainability necessitates their classification. The totality of the indicators characterizing the relations in the "society- 
nature" system is proposed to attribute to the ecological and economic indicators. The indicators of the balance type that show the ratio between "the reserves of the natural capital" and the degree of its use, taking into account compensation measures, are recommended to attribute to the indicators of sustainability;

- the value of the component-wise indicators (with a total increase in their number) is kept at the regional level, and the role of the integral indicators, including the assessment of the natural resources and human potential, increases. As part of the regional programs of ecological and economic development the componentwise indicators are used that can be transferred to the integral indicators using integrated environmental and economic accounts.

The expediency is proved and methodological approaches for the agricultural land use stability assessment has been made up: the construction of the system of indicators, each of which reflects some aspects of the land use sustainability at the macro level; the construction of the integral indicator to compare the countries' land use sustainability.

According to the given methods it has been proved that agricultural land use in the countries of the post-socialist camp has a positive dynamics, but the sustainability indicators for all indicators have not achieved yet.

It has been defined that Estonia, Latvia and Slovenia got the first three places; and Croatia, Lithuania and Romania got the last places in the ranking of sustainability of the agricultural land use for the countries of the post-socialist camp. To solve the problems in the field of the agricultural land use, Lithuania, Bulgaria, the Czech Republic, Poland, Slovakia, Latvia, Romania and Ukraine should focus on the issues of the land resources use; Poland, Slovenia, Estonia, Romania should concentrate on the issues of the efficiency of the land use; Lithuania, the Czech Republic, Poland, Croatia, Slovakia, Slovenia, Estonia and Latvia should centre on the issues of the improvement of the system of the structural changes in the economy; all countries, except for Slovenia, should focus on the issues of reducing the environmental losses; Lithuania and Estonia should be concentrated about the issues of the reduction of the environmental pollution; Croatia should stick to the issues of raising the level of employment; Lithuania, the Czech Republic, Croatia, Estonia, Latvia, Romania and Ukraine should pay attention to the issues of the preservation of ecosystem functions and biodiversity.

The obtained results should be used in the future in the construction of national and regional models of optimal use of agricultural land on the example of the study Ongsomwang and Lamchuen (2015).

\section{Acknowledgments}

This study is prepared as part of the implementation of the grant "The European experience of forming a food security system based on principles of sustainable agricultural land use development". This study was supported in part by the Erasmus SUPPA program - Jean Monnet Associations Application No 611556-EPP-1-2019-1-UAEPPJMO-SUPPA.

\section{Corresponding authors}

Kotykova Olena, Dr. of Economics, Professor, Head of the Business Economics Department Mykolayiv National Agrarian University, Georgiy Gongadze Str. 9, 54010, Mykolayiv, Ukraine

Phone: +38(099) 293-03-63; E-mail: eikotikova7@gmail.com; kotikova@i.ua

ORCID: 0000-0003-1420-1500

\section{References}

[1] Aggarwal, P. K. (2008) "Global climate change and Indian agriculture: impacts, adaptation and mitigation”, Indian Journal of Agricultural Sciences, Vol. 78, pp. 911-919. ISSN 0019-5022.

[2] Chartres, C. J. and Noble, A. (2015) "Sustainable intensification: overcoming land and water constraints on food production", Food Security, Vol. 7, pp. 235-245. E-ISSN 1876-4525, ISSN 1876-4517. DOI 10.1007/s12571-015-0425-1. 
[3] EEA (2005) "Agriculture and environment in EU-15 - the IRENA indicator report", Luxembourg: Office for Official Publications of the European Communitie. [Online]. Available: https://www.eea. europa.eu/publications/eea_report_2005_6 [Accessed: 16 Oct. 2020]. ISBN 92-9167-779-5.

[4] Elbersen, B., Beaufoy, G., Jones, G., Noij, G-J., Doorn, A., Breman, B. and Hazeu, G. (2014) "Aspects of data on diverse relationships between agriculture and the environment", Report for DG-Environment, Contract no. 07-0307/2012/633993/ETU/B1, Alterra, Wageningen, April 2014.

[5] FAO (1999) "Central and Eastern European Sustainable Agriculture Network", First Workshop. Food and Agriculture Organization of the United Nations, Rome, 1999. [Online]. Available: http://www.fao.org/3/AD238E/ad238e00.htm\#Contents [Accessed: 16 Oct. 2020].

[6] Federal State Statistics Service of Russian Federation (2015) “Agriculture" [Online]. Available: http:/www.gks.ru/wps/wcm/connect/rosstat_main/rosstat/en/figures/agriculture/_ [Accessed: 15 Dec. 2018].

[7] Federal State Statistics Service of Russian Federation.(2015) "Population" [Online]. Available: http://www.gks.ru/wps/wcm/connect/rosstat_main/rosstat/en/figures/population/ 15 Dec. 2018].

[8] Gutierrez, T. N., Rege, S., Marvuglia, A. and Benetto, E. (2017) "Sustainable Farming Behaviours: An Agent Based Modelling and Lca Perspective", In "Agent-Based Modeling of Sustainable Behaviors", edited by A. Alonso Betanzos, N. Sanchez Marono, O. Fontenla Romero, J. G. Polhill, T. Craig, J. Bajo and J. M. Corchado, Understanding Complex Systems Springer Complexity, pp. 187-206. Cham: Springer International Publishing Ag. DOI 10.1007/978-3-319-46331-5_9.

[9] Hreshchuk, H. (2019) "Efficiency of Land Management Provision of Sustainable Land Use of Agricultural", Scientific Papers-Series Management Economic Engineering in Agriculture and Rural Development, Vol. 19, No. 3, pp. 275-280. ISSN 2284-7995.

[10] Huaranca, L. L., Iribarnegaray, M. A., Albesa, F., Volante, J. N., Brannstrom, C. and Seghezzo, L. (2019) "Social Perspectives on Deforestation, Land Use Change, and Economic Development in an Expanding Agricultural Frontier in Northern Argentina”, Ecological Economics, pp. 165. ISSN 0921-8009. DOI 10.1016/j.ecolecon.2019.106424.

[11] Jansen, H. G. P., Bouman, B. A. M., Schipper, R. A., Hengsdijk, H. and Nieuwenhuyse, A. (2005) "An Interdisciplinary Approach to Regional Land Use Analysis Using Gis, with Applications to the Atlantic Zone of Costa Rica", Agricultural Economics, Vol. 32, No. 1, pp. 87-104. E-ISSN 1574-0862. DOI 10.1111/j.0169-5150.2005.00007.x.

[12] Juo, A. S. R. and Wilding, L. P. (2001) "Land and civilization: An historical perspective", In "Response to land degradation" Bridges, E. M., Hannam, I. D., Oldeman, L. R., DeVries, W. T. P., Scherr, S. J., Sombatpanit, S., Eds.; Oxford and IBH Pab. Co. Pvt. Ltd.: New Delhi, 2001, pp. 13-19.

[13] Keenleyside, C, Beaufoy, G, Tucker, G, and Jones, G (2014) "High Nature Value farming throughout EU-27 and its financial support under the CAP", Report prepared for DG Environment, Contract No. ENV B.1/ETU/2012/0035, Institute for European Environmental Policy, London. [Online]. Available: https://ec.europa.eu/environment/agriculture/studies.htm [Accessed: 16 Oct. 2020].

[14] Kotykova, O., Kuzmenko, O. and Semenchuk, I. (2019) "Sustainable agricultural land use in the post-socialist camp countries: monitoring and evaluation", Baltic Journal of Economic Studies, Vol. 5, No. 1, pp. 101-111. E-ISSN 2256-0963, ISSN 2256-0742. DOI 10.30525/2256-0742/2019-5-1-101-111.

[15] Krausmann, F., Erb, K. H., Gingrich, S., Haberl, H., Bondeau, A., Gaube, V., Lauk, C., Plutzar, C. and Searchinger, T. D. (2013) "Global human appropriation of net primary production doubled in the $20^{\text {th }}$ century", Proceedings of the National Academy of Sciences of the United States of America, Vol. 110, pp. 10324-10329. DOI 10.1073/pnas.1211349110.

[16] Lacirignola, C., Capone, R., Debs, Ph., El Bilali, H. and Bottalico, F. (2014) "Natural resources-food nexus: food-related environmental footprints in the mediterranean countries", Frontiers in Nutrition, Vol. 1, pp. 23. E-ISSN 2296-861X. DOI 10.3389/fnut.2014.00023. 
[17] Lal, R. (2000) "Soil management in the developing countries", Soil Science, Vol. 165, No. 1, pp. 57-72. ISSN 0038-075X. DOI 10.1097/00010694-200001000-00008.

[18] Lal, R. (2015) "Restoring Soil Quality to Mitigate Soil Degradation", Sustainability, Vol. 7, No. 5, pp. 5875-5895. ISSN 2071-1050. DOI 10.3390/su7055875.

[19] Marada, P., Valtyniova, S. and F. Verner (2012) "Assessing the Sustainability of Farming on Arable Land and Its Use in the Education", Mendelnet 2012, pp. 449-455. ISBN 978-80-7375-836-3.

[20] Ministry of Agrarian Policy and Food of Ukraine (2016) "The project (the draft) of the State Target Program of the development of the agricultural sector of the economy for the period to 2020". [Online]. Available: http://www.auu.org.ua/uk/publications/web/226/ [Accessed: 15 Dec. 2018].

[21] National Statistical Committee of the Republic of Belarus (2015) "Macroeconomy and anvironment" [Online]. Available: http://www.belstat.gov.by/en/ofitsialnaya-statistika/macroeconomy-andenvironment/ [Accessed: 15 Dec. 2018].

[22] National Statistical Committee of the Republic of Belarus (2015) “Agriculture and forestry" [Online]. Available: http://www.belstat.gov.by/en/ofitsialnaya-statistika/real-sector-of-the-economy/selskoehozyaistvo/ [Accessed: 15 Dec. 2018].

[23] Obando, J. O. T. (2018) "Analysis of Sociocultural Indicators of Rural Development in the Santa Rita Community, Masatepe-Masaya, 2017”, Reice-Revista Electronica De Investigacion En Ciencias Economicas, Vol. 6, no. 11, pp. 1-20. ISSN 2308-782X. DOI 10.5377/reice.v6i11.6144. (in Spain).

[24] Ongsomwang, S., and N. Iamchuen (2015) "Integration of Geospatial Models for Optimum Land Use Allocation in Three Different Scenarios", Suranaree Journal of Science and Technology, Vol. 22, no. 4, pp. 377-396. ISSN 0858-849X.

[25] Petty, W. (1769) "Tracts, chiefly relating to Ireland. Containing: I. A treatise of taxes and contributions. II. Essays in political arithmetic. III. The political anatomy of Ireland. To which is prefixed his last will", Published by Dublin, printed by Boulter Grierson.

[26] Smith, C. S. and McDonald, G. T. (1998) "Assessing the sustainability of agriculture at the planning stage”, Journal of Environmental Management, Vol. 52, No. 1. pp. 15-37. ISSN 0301-4797. DOI 10.1006/jema.1997.0162.

[27] State Statistics Service of Ukraine (2019) "Economic statistics / Economic activity / Agriculture, forestry and fishery. State Statistics Service of Ukraine" [Online]. Available: http://www.ukrstat.gov.ua/ [Accessed: 12 Feb. 2019].

[28] Taylor, D. F. (2001) "Employment-Based Analysis: An Alternative Methodology for Project Evaluation in Developing Regions, with an Application to Agriculture in Yucatan", Ecological Economics, Vol. 36, No. 2, pp. 249-262. ISSN 0921-8009. DOI 10.1016/S0921-8009(00)00235-4.

[29] Tscharntke, T., Clough, Y., Wanger, T. C., Jackson, L., Motzke, I., Perfecto, I., Vandermeer, J. and Whitbread, A. (2012) "Global food security, biodiversity conservation and the future of agricultural intensification”, Biological Conservation, Vol. 151, No. 1., pp. 53-59. ISSN 0006-3207. DOI 10.1016/j.biocon.2012.01.068.

[30] Turcekova, N., Svetlanska, T., Kollar, B., Zahorsky, T. and Brno Mendel University (2015) "Assessment of Environmental Performance of Slovak Agriculture", Proceedings Icabr 2015: X. International Conference on Applied Business Research, pp. 1069-1082. ISBN 978-80-7509-379-0.

[31] Word Data Center. (2019) "Global analysis of quality of life and security of life" [Online]. Available: http://wdc.org.ua/uk/services/country-profiles-visualization [Accessed: 12 Feb. 2019].

\section{Declaration of interest statement}

The data that support the findings of this study are openly available in State Statistics Service of Ukraine at http://www.ukrstat.gov.ua, in Federal State Statistics Service of Russian Federation at http://www.gks. ru, in National Statistical Committee of the Republic of Belarus at http://www.belstat.gov.by, in Word data Center at http://wdc.org.ua. 